\title{
Implementasi Import dan Export Database dengan Menggunakan SQL Server 2008
}

\author{
Didik Setiyadi ${ }^{1}$, Henderi ${ }^{2}$, Rita Wahyuni Arifin ${ }^{3}$ \\ ${ }^{1}$ Teknik Informatika; Universitas Bina Insani; Jl. Siliwangi No.6 Rawa Panjang Bekasi Bekasi \\ Timur 17114 Indonesia; Telp. (021) 82436 886, Fax. (021) 824009 24; \\ e-mail: didiksetiyadi@binainsani.ac.id
}

2 Teknik Informatika; Universitas Raharja; Jl.Jend.Sudirman No.40 Cikokol Kota Tangerang 15117 Indonesia; Telp. (021) 55749539, email: henderi@raharia.info

${ }^{3}$ Manajemen Informatika; Universitas Bina Insani; Jl. Siliwangi No.6 Rawa Panjang Bekasi Bekasi Timur 17114 Indonesia; Telp. (021) 82436 886, Fax. (021) 824009 24; e-mail: ritawahyuni@binainsani.ac.id

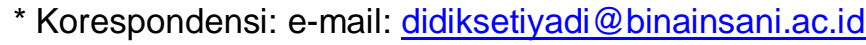

Diterima: 2 Oktober 2020; Review: 7 Oktober 2020; Disetujui: 13 Oktober 2020;

Cara sitasi: Setiyadi D, Henderi, Arifin RW. 2020. Implementasi Import dan Eksport Database Menggunakan SQL Server 2008. Informatics for Educators and Professionals. 5(1): 1 - 10.

\begin{abstract}
Abstrak: Import data adalah proses mengambil data dari database lain misalkan Microsoft Access kedalam SQL Server 2008, bisa juga Microsoft Excel yang telah kira miliki dilakukan import data kedalam SQL Server 2008. Pada import dari Microsoft Access bisa kita ambil seluruh table dan datanya atau sebagian saja yang diimport, demikian juga kalo kita akan melakukan import dari Microsoft Excel. Jika kita melakukan import dari Microsoft Access, maka primary key akan hilang dan demikian juga untuk tipe data akan berubah menyesuaikan dengan tipe data yang ada di SQL Server 2008, demikan juga jika melakukan import dari Microsoft Excel. Sedangkan pada proses export data adalah proses mengeluarkan data dari database yang ada di SQL Server 2008 kedalam database lain misalkan Microsoft Access atau bisa juga ke Microsoft Excel. Pada export data dari SQL Server 2008 ke Microsoft Access bisa kita ambil seluruh table dan datanya atau sebagian saja yang, demikian juga kalo kita akan melakukan export ke Microsoft Excel. Pada penulisan ini akan dibahas tentang bagaimana melakukan export dan import data dengan menggunakan SQL Server 2008. Langkah awal yang dilakukan adalah dengan mengambil studi kasus database Jadwal Mengajar Microsoft Access yang telah terbentuk relationshipnya beserta isi datanya. Selanjutnya bagaimana melakukan proses import database tersebut ke SQL Server 2008, membuat primary key, relasi sampai terbentuk diagram dengan menggunakan DBMS SQL Server 2008. Berdasarkan database yang telah terbentuk diagramnya tersebut akan kita lakukan export ke dalam Microsoft Excel.
\end{abstract}

Kata Kunci: Diagram, Export, Import, Jadwal Mengajar, Relasi, Relationship, Sql Server 2008

Abstract: Importing data is the process of retrieving data from other databases, for example, Microsoft Access into SQL Server 2008, Microsoft Excel, which is thought to have, is imported data into SQL Server 2008. On import from Microsoft Access, we can retrieve all tables and data or only part of it is imported, Likewise, if we are going to import from Microsoft Excel. If we import from Microsoft Access, the primary key will be lost and the data type will change according to the data type in SQL Server 2008, as well as importing from Microsoft Excel. Meanwhile, the data export process is the process of removing data from an existing database in SQL Server 2008 into another database, for example Microsoft Access or Microsoft Excel. In exporting data from SQL Server 2008 to Microsoft Access, we can take the entire table and the data or only part of it, so if we are going to export to Microsoft Excel. In this paper will discuss about how to export and import data using SQL Server 2008. The first step is to take a case 
study of the Microsoft Access Teaching Schedule database that has formed a relationship and its data contents. Furthermore, how to import the database into SQL Server 2008, create primary keys, relationships to form diagrams using the SQL Server 2008 DBMS. Based on the database that has formed the diagrams, we will export it into Microsoft Excel.

Keywords: Diagram, Export, Import, Relation, Relationship, Sql Server 2008, Teaching Schedule

\section{Pendahuluan}

Sistem informasi merupakan suatu framework yang mengkoordinasikan sumber daya (manusia dan teknologi komputer) untuk mengubah input (masukan) menjadi output (keluaran) menjadi informasi yang berguna dalam mencapai saran-saran yang telah ditetapkan perusahaan [1]. Jika berbicara sistem informasi, biasanya data disimpan dalam database yang saling terintegrasi dari data yang satu dengan lainnya untung menghasilkan informasi yang akurat yang dapat dimanfaatkan oleh pengguna (user). Informasi dapat dikatakan sebagai sekumpulan data dan fakta yang terorganisir yang diolah dengan cara terentu dan dapat dimanfaatkan oleh penerima (pengguna) di dalam suatu organisasi [2]. Sistem Manajemen Basis Data (SMBD) merupakan koleksi terpadu dari aplikasi program (system software) yang dapat dimanfaatkan dalam pendefinisian basis data, membuat basis data, melakukan akses basis data dan memelihara basis data [3]. Basis data merupakan koleksi terpadu dari data, dimana data-data terebut disimpan pada tabel-tabel yang saling terintegrasi yang bertujuan untuk menghasilkan informasi bagi pengguna dalam suatu perusahaan [3]

Pertumbuhan lalu lintas data dalam komunikasi client-server membutuhkan strategi khusus agar memberikan waktu respons rendah. Pada proses pencarian yang seringkali melibatkan query yang rumit, cara untuk mengurangi waktu proses ini adalah dengan melakukan proses indexing dengan menggunakan Apache Solr sebagai platform. Fitur dari Apache Solr adalah melakukan import, yaitu full-import dan deltaimport dari basis data MySQL ke dalam Solr. Dalam penelitian ini dilakukan proses import seluruh atau parsial [4].

Microsoft SQL Server merupakan software RDBMS kelompok enterprise yang sering dimanfaatkan di perusahaan korporasi. Dengan menggunakan SQL Server, user dapat melakukan penyimpanan data dan mengimplementasikannya untuk kegiatan bisnis dalam dunia usaha dan industri [5]. SQL merupakan bahasa khusus yang dipergunakan dalam melakukan akses dan melakukan pengelolaan RDBMS [3]. Data Transformation Service (DTS) digunakan untuk melakukan transfer data dari format SQL Server kedalam format database lainnya seperti Access, Excel dan atau sebaliknya. Didalam penggunaan DTS memungkinkan kita dapat melakukan export atau melakukan import data yang ada dalam database kita [6].

Panduan import dan export adalah metode termudah untuk memindahkan sumber data seperti oracle, DB2, SQL Server, dan file teks ke hampir semua tujuan dan tersedia di semua versi SQL Server, bahkan mereka yang tidak memiliki SSIS. Seperti alat SSIS lainnya, ada banyak cara untuk membuka alat tersebut, untuk membuka wizard import export, klik kanan database tempat Anda ingin mengimpor data atau mengekspor data ke dalam SQL Server Management Studio dan pilih task import data (atau export data berdasarkan apa yang Anda lakukan [7]. Diagram basis data menggambarkan hubungan tabel-tabel yang ada dalam database yang dibuat, dalam diagram bisa juga dilihat definisi atribut-atribut (column), primary key, relasi antar tabel dan constraint foreign key dari hubungan antar tabel yang telah terbentuk [8]. Sedangkan relationship adalah hubungan atau relasi antar tabel yang telah terbentuk, relasi tidak harus dibuat, namun jika dibuat akan memberikan manfaat diantaranya memudahkan dalam pembuatan query, dimana relasi antar tabel otomatis mengikti refinisi relationship, memudahkan menerapkan referential integrity atau aturan referensi untuk menjaga integritas data serta memudahkan mengingat kunci-kunci yang menghubungkan data antar tabel, karena definisi relationship bisa dilihat secara visual dan tersimpan [9]

Berdasarkan penjelasan diatas, dalam penelitian ini akan dibahas tentang bagaimana membuat melakukan import dan export database dari SQL Server 2008 kedalam database Microsoft Access dan atau sebaliknya. Studi kasus yang digunakan adalah dengan menggunakan database Jadwal Mengajar, dimana relationship database tersebut telah dibuat pada Microsoft Acces. 


\section{Metode Penelitian}

Literature review atau sering dikatakan sebagai studi pustaka adalah bagian dari karya tulis ilmiah yang memuat pembahasan tentang penelitian yang telah dilakukan sebelumnya serta referensi ilmiah yang terkait dengan penelitian yang dijelaskan oleh penulis dalam karya tulis yang dilakukan [10]. Kajian pustaka adalah konsep teori pendukung yang melandasi problem yang kita kaji serta membahas hasil penelitian sebelumnya yang telah dilakukan oleh peneliti lain dengan topik yang sama [11].

Database System Development Life Cycle (DSDLC) adalah metode pengembangan database meliputi tahapan planning database, definisi sistem, analisis dan pengumpulan kebutuhan, design database, selection database, design aplikasi, prototype, implementation, konversi data, testing dan pemeliharaan sistem [12]. Pada pelaksanaaan penelitian ini dibatasi pada tahapan implementasi basis data menggunakan SQL Server 2008 dari database relationhsip Microsoft Access yang telah terbentuk sampai dengan melakukan import data dari Microsft Access ke SQL Server 2008 dan export data dari SQL Server 2008 ke Microsoft Access.

Berikut ini adalah kerangka pemikiran yang merupakan langkah-langkah yang dilakukan dalam mengimplementasikan proses impot data dan export data dari database Jadwal Mengajar dalam bentuk relationship yang telah diimplementasi dengan Microsoft Access.

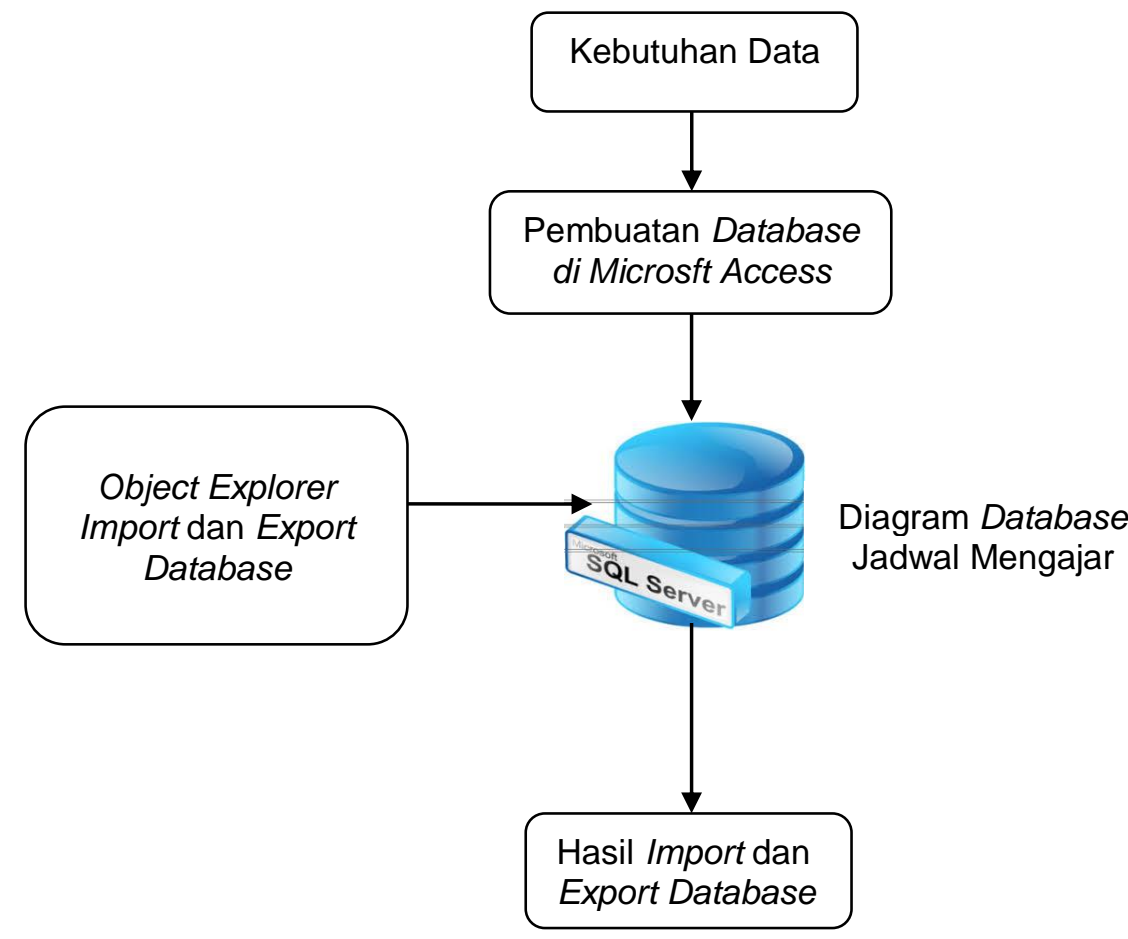

Sumber: Hasil Penelitian (2020)

\section{Gambar 1. Kerangka Pemikiran}

Penjelasan dari Gambar 1 tahapan awal yang dilakukan yaitu mendapatkan kebutuhan data yaitu dengan mendapatkan database Jadwal Mengajar dari Microsoft Access dalam bentuk implementasi dari tabel-tabel insert data, relasi sampai telah terbentuk relationshipnya. Selanjutnya dilakukan implementasi import database tersebut kedalam RDBMS Sql Server 2008, pembuatan primary key nya, relasi sampai terbentuk diagram. Setelah sukses melakuan import data langkah selenjutnya, database Jadwal Mengajar terebut selanjutnya kita export kembali ke database Microsoft access. 


\section{Hasil dan Pembahasan}

\subsection{Diagram Database}

Gambar 2 dibawah menunjukkan relationship database Jadwal Mengajar yang telah dibuat dengan menggunakan Microsoft Access yang dimulai dari pembuatan database, pembuatan tabel, isi data, relasi sampai terbentuk relationship pada gambar 2 berikut ini:

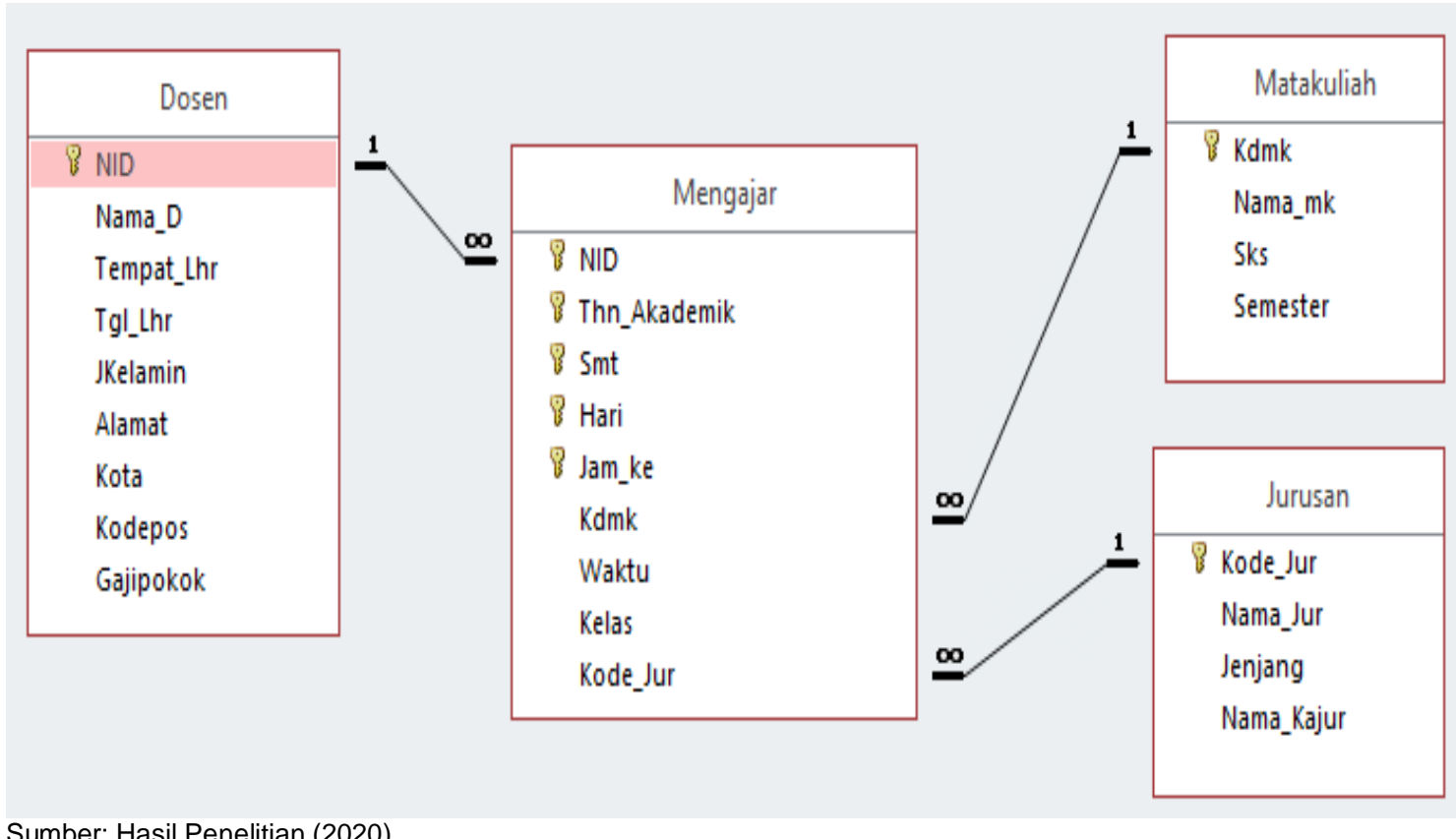

Sumber: Hasil Penelitian (2020)

\section{Gambar 2. Relationship Jadwal Mengajar}

Pada relationship database Jadwal Mengajar tersebut terdiri dari 4 (empat) tabel yaitu Dosen, Jurusan, Mengajar, dan Matakuliah. Relasi yang terjadi antar tabel terdiri dari 3 (tiga) yaitu Jurusan ke Mengajar (one to many), Dosen ke Mengajar (one to many), dan Matakuliah ke Mengajar (one to many). Adapun struktur tabel dosen, matakuliah, mengajar dan matakuliah seperti terlihat pada Gambar 3 berikut ini:

\begin{tabular}{|c|c|c|c|c|c|c|c|c|}
\hline NID . & Nama_D & Tempat_Lhr - & Tgl_Lhr & JKelamin & Alamat & Kota & Kodepos. & Gajpokok \\
\hline \pm 00001 & & Bogor & 24/12/197 & 4 Pria & Jl.Catur 3 No. 23 & Bekasi Utara & 52123 & Rp1.300.000 \\
\hline \pm 00002 & Hasta Riyanti,Ir,MM & Jakarta & $27 / 05 / 196$ & 9 Wanita & Jl.Delima 2 No.2 & Bekasi Timur & 45612 & Rp1.150.000 \\
\hline$\mp 01001$ & Cokro Diningrat,IIr,MT & Bekasi & $19 / 12 / 196$ & 6 Pria & I.Dayang Raya 2 No.12 & Cibitung & 54456 & Rp1.200.000 \\
\hline \pm 01002 & Sakib Aljaber,MT & Cikarang & 20/05/197 & Pria & Jl.Kemunig 1 No.1 & Cikarang & 56234 & Rp1.150,000 \\
\hline † 95001 & Bambang Sutedjo,lr,MMSi & Jakarta & $23 / 02 / 195$ & 8 Pria & J.Mawar 6 No.2 & Jakarta Selatan & 23234 & Rp1.300,000 \\
\hline$\mp 95002$ & Asri Kasetyaningsih, M.Kom & Semarang & $25 / 12 / 196$ & 2 Wanita & Jl.Perjuangan 3 No.11 & Bekasi Timur & 54567 & Rp1.200.000 \\
\hline$\mp 96001$ & Triyatno,Ir,MM,M.Kom & Bekasi & $14 / 05 / 196$ & & Jl.Mawar Indah 1 No.1 & Bekasi Barat & 54356 & Rp1:100,000 \\
\hline \pm 96002 & Diastuti Pujiningsih,MM,MT & Surabaya & $24 / 12 / 197$ & Wanita & Jl.Jarur Kuning 2 No.56 & Cibitung & 54566 & Rp1.000.000 \\
\hline \pm 97001 & Endang Junianti,II,MMSi & Bandung & 20/05/196 & 7 Wanita & J.Kemukus 2 No 56 & Cikarang & 56555 & Rp1.150.000 \\
\hline \pm 97002 & Djoko Pamungkas,M.Kom & Bogor & $23 / 05 / 1$ & 1 Pria & Jl.Anggrek $7 \mathrm{~N} 0.1$ & Bekasi Timur & 45666 & Rp1,100,000 \\
\hline$\mp 98001$ & Didik Atmadja,Ir,MMSi & Bandung & $20 / 04 / 19$ & Pria & Jl.Cipete Raya No.6 & Jakarta Selatan & 24123 & Rp1.250.000 \\
\hline \pm 98002 & Bagus Windarjo,M.Kom & Tangerang & $13 / 12 / 19$ & & J.H.Ali No.21 & Cibitung & 54523 & Rp1.150.000 \\
\hline † 99001 & Dewi Anjani,Ir,MM & Bekasi & $14 / 12 / 197$ & 5 Wanita & Jl.Kemang Raya 2 No.1 & Bekasi Barat & 54567 & Rp1.200.000 \\
\hline
\end{tabular}




\begin{tabular}{|c|c|c|c|c|c|c|c|c|c|c|c|c|c|c|}
\hline & \multicolumn{3}{|c|}{ Kdmk } & \multicolumn{8}{|c|}{ Nama_mk } & Sks . & \multicolumn{2}{|c|}{ Semester } \\
\hline$\Phi$ & \multirow{2}{*}{\multicolumn{3}{|c|}{$\begin{array}{l}\text { МКВ331201 } \\
\text { MKB331203 }\end{array}$}} & \multicolumn{8}{|c|}{ PENGANTAR TEKNOLOGI INFORMASI } & \multicolumn{3}{|c|}{31} \\
\hline$\oplus$ & & & & \multirow{2}{*}{\multicolumn{8}{|c|}{$\begin{array}{l}\text { PRAKTIKUM PAKET PROGRAM APLIKASI I } \\
\text { PERANCANGAN BASIS DATA }\end{array}$}} & \multicolumn{3}{|c|}{11} \\
\hline$\Phi$ & \multicolumn{3}{|c|}{ MKB331205 } & & & & & & & & & \multicolumn{3}{|c|}{42} \\
\hline$\oplus$ & \multicolumn{3}{|c|}{ МKB331206 } & \multicolumn{8}{|c|}{ PAKET PROGRAM APLIKASI II } & & 12 & \\
\hline$\Phi$ & \multicolumn{3}{|c|}{ МKB331209 } & \multicolumn{8}{|c|}{ ALGORITMA PEMROGRAMAN I (PASCAL) } & \multicolumn{3}{|c|}{32} \\
\hline$\Phi$ & \multirow{2}{*}{\multicolumn{3}{|c|}{$\begin{array}{l}\text { МКB331210 } \\
\text { MKK231201 }\end{array}$}} & \multicolumn{8}{|c|}{ PRAK.ALGORITMA PEMROGRAMAN I (PASCAL) } & \multicolumn{3}{|c|}{12} \\
\hline \pm & & & & \multirow{2}{*}{\multicolumn{8}{|c|}{$\begin{array}{l}\text { DASAR MANAJEMEN DAN BISNIS I } \\
\text { DASAR MANAJEMEN DAN BISNIS II }\end{array}$}} & \multicolumn{3}{|c|}{21} \\
\hline+ & \multicolumn{3}{|c|}{ МKK231202 } & & & & & & & & & & 22 & \\
\hline$\Phi$ & \multicolumn{3}{|c|}{ МКK231203 } & \multicolumn{8}{|c|}{ MATEMATIKA DISKRIT } & & 21 & \\
\hline$\Phi$ & MKK2 & 3120 & & MATEMAT & KA DISKR & |T II & & & & & & & 22 & \\
\hline$\Phi$ & MKK2 & 3120 & & AKUTANS & DASAR I & & & & & & & & 21 & \\
\hline+ & МKK2 & 3120 & & AKUTANS & DASAR II & & & & & & & & 22 & \\
\hline \pm & МKК2 & 3121 & & PENGANT & REKONO & & & & & & & & 21 & \\
\hline+ & MPK1 & 3120 & & PENDIDIK & N AGAM & & & & & & & & 21 & \\
\hline & MPK1 & 3120 & & PENDIDIK & N PANCA & SILA & & & & & & & 21 & \\
\hline & MPK1 & 3120 & & PENDIDIK & N KEWAR & GAI & NEGAR & AN & & & & & 22 & \\
\hline & MPK1 & 3120 & & BAHASA I & GGRIS I & & & & & & & & 21 & \\
\hline & MPK1 & 3120 & & BAHASA I & GGRIS II & & & & & & & & 22 & \\
\hline & MPK2 & 3120 & & SISTEM B & IS DATA & & & & & & & & 21 & \\
\hline & Kode_J & ur - & & Name & & & Jer & ijan & $\lg \cdot$ & & Nan & na_Kajur & & \\
\hline$\pm \mathrm{K}$ & KA & & Komp & puterisasi & untansi & & Diplc & ma & & Rini & Wulandari, & MM,MM & ISi. & \\
\hline $\pm N$ & MI & & Manaj & ajemen Inf & matika & & Diplc & oma & & Wah & hono Diproj & $0, \mathrm{MM}, \mathrm{M}$ & И.Kor & \\
\hline $\pm S$ & SI & & Sisten & m Informa & & & Strat & & & Bagu & us Hermans & ;yah, MM. & A.Si, N & M.Kom. \\
\hline$\pm \mathrm{T}$ & TI & & Tekhn & nik Inform & & & Start & & & Fadj & jar Sasongk & o, MT, M. & I.Kom & \\
\hline$\pm \mathrm{T}$ & TK & & Tekhn & nik Kompu & & & Diplc & oma & & Agus & s Budiyanta & $\mathrm{ra}, \mathrm{T}, \mathrm{MT}$. & & \\
\hline & NID & Thn & n_Akader & Smt & Hari & - & Jam_ke & - & Kdmk & k & Waktu . & Kelas & - & Kode_Jur \\
\hline 000 & 001 & 200 & & 1 & Rabu & & 1 & & MKB3312 & & 8:00 & T202 & & TI \\
\hline & 001 & 200 & & 1 & Senin & & 1 & & MKB3312 & & 8:00 & M101 & & MI \\
\hline & 002 & 200 & & 2 & Jum'at & & 1 & & MPK1312 & & 8:00 & $\$ 201$ & & SI \\
\hline & 002 & 200 & & 2 & Jum'at & & 2 & & MPK1312 & & 10:00 & $\$ 202$ & & SI \\
\hline & 001 & 200 & & 1 & Kamis & & 1 & & MKB3312 & & 8:00 & T101 & & TI \\
\hline & 001 & 200 & & 1 & Senin & & 1 & & MKB3312 & & 8:00 & M101 & & Ml \\
\hline & 3002 & 200 & & 2 & Rabu & & 1 & & MKB3312 & & 8:00 & S201 & & SI \\
\hline & 3002 & 200 & & 2 & Selasa & & 2 & & MPK1312 & & $10: 00$ & M201 & & MI \\
\hline & 3001 & 200 & & 1 & Senin & & 1 & & MKB3312 & & 8:00 & M102 & & MI \\
\hline & 3001 & 200 & & 2 & Selasa & & 1 & & MKB3312 & & 8:00 & T201 & & TI \\
\hline
\end{tabular}

Gambar 3. Integrasi data database Jadwal Mengajar

\subsection{Implementasi Import Data}

Implementasi import data dengan SQL Server 2008, dimana database yang akan di import adalah Jadwal Mengajar yang terdiri dari 4 (empat) table yang ada di database Microsoft Access yang terlihat pada gambar 2 dan gambar 3. Adapun langkah-langkah dalam melakukan import dimana kita harus berada pada object explorer di SQL Server 2008 adalah pada tabel 1 sebagai berikut ini: 
Tabel 1. Langkah import database Jadwal Mengajar dari Access ke SQL Server

\begin{tabular}{lll} 
No & \multicolumn{1}{c}{ Langkah } & \multicolumn{1}{c}{ Keterangan } \\
\hline 1. & $\begin{array}{l}\text { Buat database baru di SQL Server } \\
\text { "ImportJadwalMengajar" }\end{array}$ & $\begin{array}{l}\text { Nama database harus UNIK tidak boleh ada yang } \\
\text { sama }\end{array}$ \\
\hline 2. & $\begin{array}{l}\text { Pada database Import JadwalMengajar, klik kanan lalu } \\
\text { Tasks, Import Data }\end{array}$ & $\begin{array}{l}\text { Pastikan bahwa database posisi yang benar di } \\
\text { ImportJadwalMengajar }\end{array}$ \\
\hline 3. & $\begin{array}{l}\text { Pada data sources, pilih : Microsoft Access. Lalu pada } \\
\text { file name, pilih Browse, lalu cari database Access } \\
\end{array}$ & $\begin{array}{l}\text { User name dan pasword abaikan, jika pada saat } \\
\text { instalasi sql server 2008 diberi, isi user name dan } \\
\text { pasword nya }\end{array}$ \\
\hline 4. & $\begin{array}{l}\text { Pada destinitation, server name dan database abaikan, } \\
\text { buat default karena kita sudah menempatkan pada } \\
\text { database ImportJadwalMengajar, lalu next }\end{array}$ & $\begin{array}{l}\text { Apabila kita tidak menempatkan pada database } \\
\text { ImportJadwalMengajar, maka destinitation, server } \\
\text { name dan database harus disesuaikan }\end{array}$ \\
\hline 5. & $\begin{array}{l}\text { Klik : Copy data from one or more tables or views, lalu } \\
\text { next }\end{array}$ & $\begin{array}{l}\text { Akan dilakukan copy terhadap seluruh table dan } \\
\text { data pada database Access JadwalMengajar }\end{array}$ \\
\hline 6. & $\begin{array}{l}\text { Pada tables and views: klik dosen, jurusan, matakuliah } \\
\text { dan mengajar, lalu next, next baru finish, close }\end{array}$ & $\begin{array}{l}\text { Proses import sedang berjalan (proses) sampai } \\
\text { terjadi success semua table yang di import }\end{array}$
\end{tabular}

Sumber : Hasil Penelitian (2020)

Setelah import sukses dilakukan dari database JadwalMengajar Acces ke ImportJadwalMengajar di SL Server 2008, maka 4 (empat) tabel dosen, matakuliah, mengajar dan matakuliah akan masuk kedalam tabel di SQL Server 2008. Jika kita lihat hasil import nya, maka untuk primary key akan hilang, tipe data akan berubah, dan relasi akan hilang.

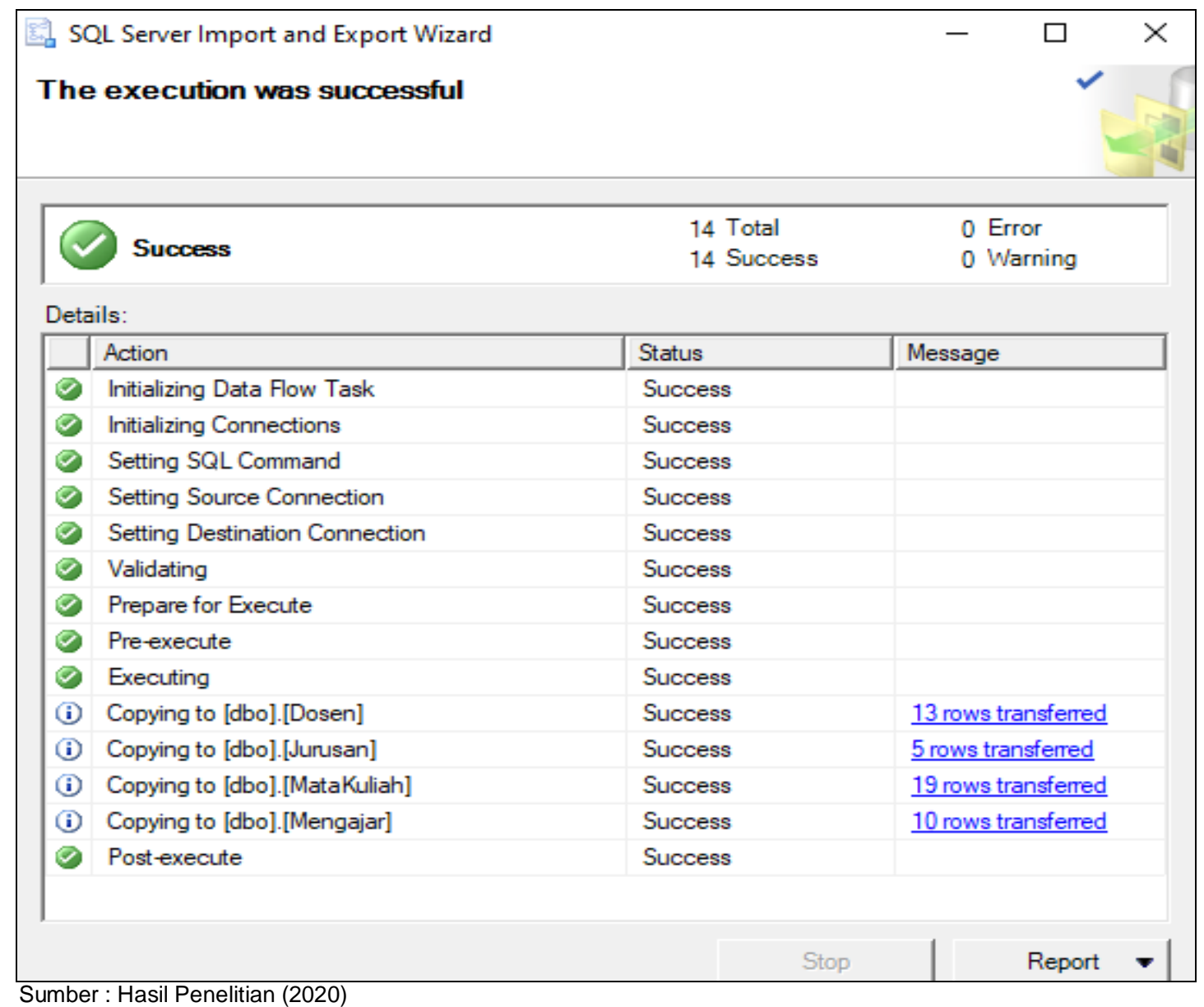

Gambar 4. Hasil import dari database JadwalMengajar ke ImportJadwalMengajar

Langkah berikutnya adalah kita akan membuat primary key dengan menggunakan query editor di SQL Server 2008 untuk 4 (empat) tabel dosen, matakuliah, mengajar dan matakuliah, pada tabel 2 berikut ini: 
Tabel 2. Membuat primary key (primary key constraint) tabel dosen, matakuliah, mengajar dan matakuliah

\begin{tabular}{|c|c|c|}
\hline No & Sintaks SQL & Keterangan \\
\hline 1. & $\begin{array}{l}\text { alter table Dosen } \\
\text { alter column NID nvarchar }(5) \text { Not Null } \\
\text { alter table Dosen } \\
\text { add constraint pkdosen primary key(NID) }\end{array}$ & $\begin{array}{l}\text { Membuat primary key table dosen, NID harus } \\
\text { dirubah ke Not Null, karena pada saat import } \\
\text { berubah menjadi Null, baru dibuat primary key } \\
\text { nya }\end{array}$ \\
\hline 2. & $\begin{array}{l}\text { alter table Matakuliah } \\
\text { alter column kdmk nvarchar }(9) \text { Not Null } \\
\text { alter table Matakuliah } \\
\text { add constraint pkmatkul primary key(kdmk) }\end{array}$ & $\begin{array}{l}\text { Membuat primary key table matakuliah, kdmk } \\
\text { harus dirubah ke Not Nuh, karena pada saat } \\
\text { import berubah menjadi Null, baru dibuat } \\
\text { primary key nya }\end{array}$ \\
\hline 3. & $\begin{array}{l}\text { alter table Jurusan } \\
\text { alter column Kode_Jur nvarchar(2) Not Null } \\
\text { alter table Jurusan } \\
\text { add constraint pkjurusan primary key(Kode_Jur) }\end{array}$ & $\begin{array}{l}\text { Membuat primary key table jurusan, kode_jur } \\
\text { harus dirubah ke Not Nuh, karena pada saat } \\
\text { import berubah menjadi Null, baru dibuat } \\
\text { primary key nya }\end{array}$ \\
\hline 4. & $\begin{array}{l}\text { alter table Mengajar } \\
\text { alter column NID nvarchar(5) Not Null } \\
\text { alter table Mengajar } \\
\text { alter column Thn_Akademik nvarchar(5) Not Null } \\
\text { alter table Mengajar } \\
\text { alter column Smt nvarchar(2) Not Null } \\
\text { alter table Mengajar } \\
\text { alter column Hari nvarchar(10) Not Null } \\
\text { alter table Mengajar } \\
\text { alter column Jam_ke nvarchar(2) Not Null } \\
\text { alter table Mengajar } \\
\text { add constraint pkmengajar primary } \\
\text { key(NID,Thn_Akademik,Smt,Hari,Jam_ke) }\end{array}$ & $\begin{array}{l}\text { Membuat primary key table mengajar, NID, } \\
\text { Thn_akademik, Smt,Hari,Jam_ke harus dirubah } \\
\text { ke Not Null, karena pada saat import berubah } \\
\text { menjadi Null, baru dibuat primary key nya }\end{array}$ \\
\hline
\end{tabular}

Setelah semua tabel dibuat primary key, langkah selanjutnya adalah membuat relasi dari dosen ke mengajar, matakuliah ke mengajar dan jurusan ke mangajar seperti pada table 3 berikut ini:

Tabel 3. Membuat relasi tabel (foreign key constraint)

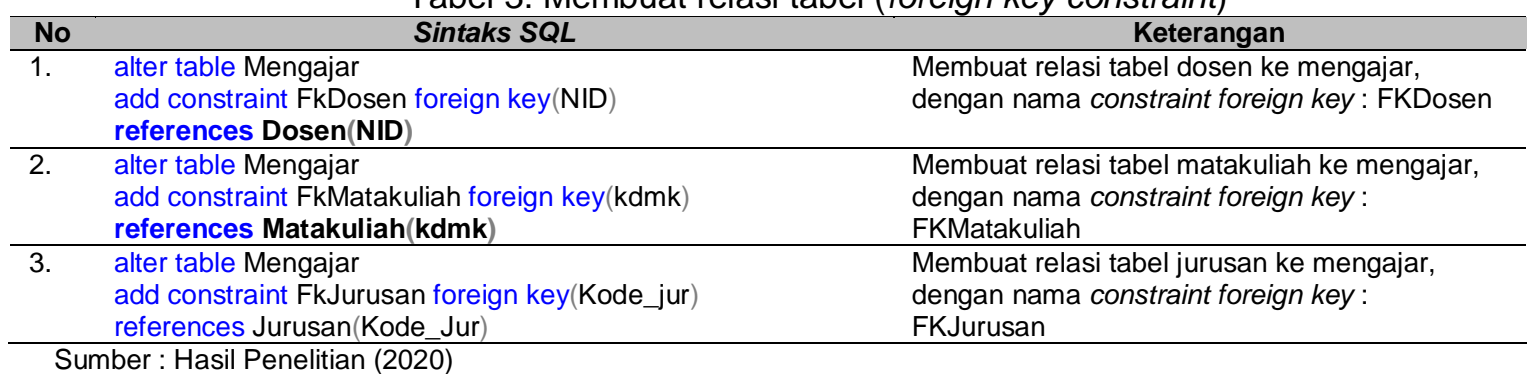

Setelah semua tabel dibuat primary key dan relasi dari tabel dosen ke tabel mengajar, tabel matakuliah ke tabel mengajar dan tabel jurusan ke tabel mangajar, hasil akhir adalah berupa diagram database ImportJadwalMengajar, diagram ini merupakan gabungan dari seluruh tabel yang telah dirancang sebelumnya, untuk lebih jelasnya maka digambarkan seperti pada gambar 5 berikut ini : 


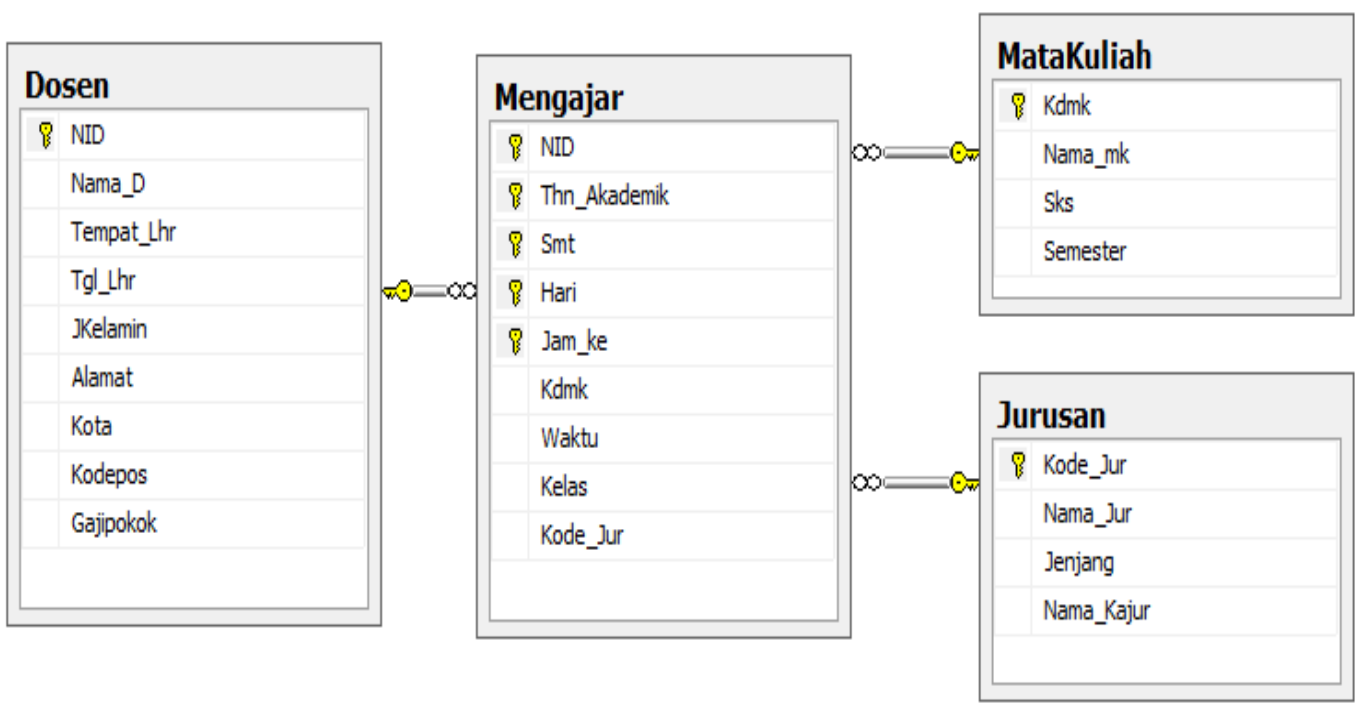

Sumber : Hasil Penelitian (2020)

Gambar 5. Diagram ImportJawalMengajar di SQL Server 2008

\subsection{Implementasi Export Data}

Implementasi import data dengan SQL Server 2008, dimana database yang akan di export adalah database ImportJadwalMengajar seperti diagram pada gambar 5, yang terdiri dari 4 (empat) table dosen, matakuliah, jurusan dan mengajar ke database Microsoft Access. Adapun langkah-langkah dalam melakukan export dimana kita harus berada pada object explorer di SQL Server 2008 sebagai berikut ini:

Tabel 4. Langkah export database ImportJadwalMengajar dari SQL Server ke Access

\begin{tabular}{|c|c|c|}
\hline No & Langkah & Keterangan \\
\hline 1. & $\begin{array}{l}\text { Buat database baru di Microsoft Access dengan nama } \\
\text { "ExportJadwalMengajar" }\end{array}$ & $\begin{array}{l}\text { Pastikan bawa, versi access yang lama (2002- } \\
\text { 2003) saja pada saat anda melakukan save } \\
\text { database kosong tersebut }\end{array}$ \\
\hline 2. & $\begin{array}{l}\text { Dengan menggunakan Object Explorer di SQL Server, klik } \\
\text { database ImportJadwalMengajar, lalu klik kanan, Tasks, } \\
\text { Export Data }\end{array}$ & $\begin{array}{l}\text { Pastikan bahwa database yang akan di export } \\
\text { pada posisi yang benar di } \\
\text { ImportJadwalMengajar }\end{array}$ \\
\hline 3. & $\begin{array}{l}\text { Pada data source, pilih SQL Server Native Client 10,0, } \\
\text { Server name sesuai dengan server anda, Database pilih } \\
\text { ImportJadwalMengajar, lalu Next }\end{array}$ & $\begin{array}{l}\text { Pada authentification, pilih use windows } \\
\text { authentification }\end{array}$ \\
\hline 4. & $\begin{array}{l}\text { Pada destinition, pilih Microsoft Acess, pada File name } \\
\text { lakukan Browse, cari dimana folder menyimpan database } \\
\text { ExportJadwalMengajar ditempatkan, lalu klik } 2 \text { kali (atau } \\
\text { open), lalu Next }\end{array}$ & $\begin{array}{l}\text { User name dan pasword abaikan, jika pada } \\
\text { saat instalasi sql server } 2008 \text { diberi, isi user } \\
\text { name dan pasword nya }\end{array}$ \\
\hline 5. & Klik : Copy data from one or more tables or views, lalu next & $\begin{array}{l}\text { Akan dilakukan copy terhadap seluruh table } \\
\text { dan data pada database } S Q L \text { Server } \\
\text { ImportJadwalMengajar ke database Access di } \\
\text { ExportJadwalMengajar }\end{array}$ \\
\hline 6. & $\begin{array}{l}\text { Pada tables and views: klik dosen, jurusan, matakuliah dan } \\
\text { mengajar, lalu next, next baru finish, close }\end{array}$ & $\begin{array}{l}\text { Pstikan tabel dosen, jurusan, matakuliah dan } \\
\text { mengajar telah dipilih semuanya }\end{array}$ \\
\hline 6. & $\begin{array}{l}\text { Pada Review data type mapping, On error (global) pilih di } \\
\text { listbox: Ignore, pada On Truncation (global) pilih di listbox: } \\
\text { Ignore, lalu Next }\end{array}$ & Pastikan semua table pada poin 5 telah benar \\
\hline 7. & $\begin{array}{l}\text { Klik Run immediately, lalu Next, lalu Finish, lalu Close, maka } \\
\text { proses export telah sukses dilakukan }\end{array}$ & $\begin{array}{l}\text { The execution wa successful jika semua tabel } \\
\text { telah sukses dilakukan transferres }\end{array}$ \\
\hline 8. & $\begin{array}{l}\text { Lakukan open database Access dengan nama } \\
\text { ExportJadwalMengajar }\end{array}$ & $\begin{array}{l}\text { Buka database yang telah sukses dilakukan } \\
\text { export }\end{array}$ \\
\hline
\end{tabular}

Dengan langkah-langkah diatas maka anda telah sukses melakukan export dari database ImportJadwalMengajar di SQL Server 2008 kedalam database ExportJadwalMengajar ke 
Microsot Access. Akan tetap seperti pada saat kita melakukan import maka seluruh primary key dan tipe data akan berubah. Di Access bisa juga kita membuat sintaks sql untuk melakukan pembuatan primary key constraint dan foreign key constraint (relasi antar table), hasil akhir akan terbentuk relationship.

Tabel 5. Langkah membuat primary key constraint dan foreign key constraint pada Microsoft Access

\begin{tabular}{|c|c|c|}
\hline No & Langkah & Keterangan \\
\hline 1. & Buka database pada Microsoft Access "ExportJadwalMengajar" & $\begin{array}{l}\text { Pastikan file database } \\
\text { ExportJadwalMengajar yang dibuka } \\
\text { sesuai termasuk lokasi } \\
\text { penyimpanannya }\end{array}$ \\
\hline 2. & $\begin{array}{l}\text { Lalu klik Create, klik Query Design, lalu Close, klik SQL, maka akan } \\
\text { tampil editor query, lalu ketik sintaks berikut untuk membuat primary } \\
\text { key tabel dosen: } \\
\text { alter table Dosen } \\
\text { add constraint PKDosen primary key(NID) } \\
\text { Lalu klik Run, lalu Save query nya }\end{array}$ & $\begin{array}{l}\text { Pada query membuat primary key tidak } \\
\text { bisa semua dibuat secara berbarengan } \\
\text { dalam satu editor seperti di SQL Server, } \\
\text { dalam Access harus satu-satu } \\
\text { disampan dan dijalankan setiap sintaks } \\
\text { query nya. }\end{array}$ \\
\hline 3. & $\begin{array}{l}\text { Membuat primary key jurusan, matakuliah dan mengajar: } \\
\text { alter table Matakuliah } \\
\text { add constraint PKMatkul primary key(kdmk) } \\
\text { alter table Jurusan } \\
\text { add constraint PKJur primary key(kode_jur) } \\
\text { alter table Mengajar } \\
\text { add constraint PKAjar primary } \\
\text { key(NID,Thn_Akademik,Smt,Hari,Jam_ke) }\end{array}$ & $\begin{array}{l}\text { Membuat primary key tabel jurusan, } \\
\text { matakuliah dan mengajar, untuk nama } \\
\text { constraint tidak boleh ada yang sama }\end{array}$ \\
\hline 4. & $\begin{array}{l}\text { Selanjutnya membuat foreign key constraint dosen ke mengajar, } \\
\text { matakuliah ke mengajar dan jurusan ke mengajar: } \\
\text { alter table mengajar } \\
\text { add constraint FkDosen foreign key(NID) } \\
\text { references Dosen(NID) } \\
\text { alter table mengajar } \\
\text { add constraint FkMatkul foreign key(kdmk) } \\
\text { references matakuliah(kdmk) } \\
\text { alter table mengajar } \\
\text { add constraint FkJur foreign key(kode_jur) } \\
\text { references jurusan(kode_jur) }\end{array}$ & $\begin{array}{l}\text { Pada prinsipnya sama sintaks query } \\
\text { untuk membuat relasi antar tabel } \\
\text { dengan menggunakan SQL Server } \\
\text { maupun MS Access }\end{array}$ \\
\hline
\end{tabular}

\section{Kesimpulan}

Berdasarkan hasil implementasi import dan export dari database Microsoft Access ke SQL Server 2008 atau sebaliknya dengan menggunakan kasus database Jadwal Mengajar disimpulkan sebagai berikut: 1). Proses import dan export dilakukan dengan menggunakan object explorer di SQL Server 2008. 2). Database untuk melakukan uji terhadap proses import dan export dengan menggunakan database Jadwal Mengajar dengan menggunakan RDBMS SQL Server 2008. 3). Hasil uji dengan melakukan import dari database Jadwal Mengajar di Access ke database ImportJadwalMengajar sukses dilakukan sampai dengan pembuatan primary key constraint, foreign key constraint dan pembuatan diagram. 4). Sedangkan hasil uji dengan melakukan export dari database ImportJadwalMengajar di SQL Server ke database ExportJadwalMengajar ke Access sukses dilakukan sampai dengan pembuatan sintaks query dari primary key constraint, foreign key constraint dan terbentuknya relationship.

\section{Referensi}

[1] Suryadharma and T. Budyastuti, Sistem Informasi Manajemen. Jawa Timur: Uwais Inspirasi Indonesia, 2019.

[2] E. Y. Anggraeni and R. Irviani, Pengantar Sistem Informasi. Yogyakarta: CV. Andi Offset, 2019.

[3] D. Setiyadi, Sistem Basis Data dan Structured Query Language (SQL). Bekasi: PT. Mitra Wacana Media.

[4] V. N. Anwar, "Implementasi Data Import Apache Solr Untuk Keperluan Indexing Data Buku," vol. 9, pp. 50-59, 2019.

[5] D. Setiyadi and D. Abdullah, Mudah dan Cepat Belajar Database dengan SQL Server 2008. Lhokseumawe: Sefa Bumi Persada, 2020.

[6] M. R. Arief, Pemrograman Basis Data Menggunakan Transact-SQL dengan Microsoft 
SQL Server 2000. Yogyakarta: CV. Andi Offset, 2006.

[7] B. Knight, E. Veerman, G. Dickinson, D. Hinson, and D. Herbold, Microsoft SQL Server 2008 Integration Services. Canada: Wiley Publishing, 2008.

[8] A. Nugroho, Mengembangkan Aplikasi Basis Data Menggunakan C\#+SQL Server. Yogyakarta: Andi, 2010.

[9] H. Talib, Panduan Lengkap MS Access 2013. Jakarta: PT. Elex Media Komputindo, 2014.

[10] I. Hermawan, Metodologi Penelitian Pendidikan, Kuantitatif, Kualitatif dan Mixed Methode. Kuningan: Hidayatul Quran Kuningan, 2019.

[11] R. Fiva, Pintar Menulis Karangan Ilmiah, Kunci Sukses Dalam Menulis IImiah. Yogyakarta: Andi, 2010.

[12] Indrajani, Database Design All in One (Theory, Practice and Case Study). Jakarta: PT Elex Media Komputindo, 2018. 